\title{
IDENTIFYING ROBUST PROXIES OF GONAD MATURATION FOR THE PROTANDROUS HERMAPHRODITE TRIDACNA MAXIMA (RÖDING, 1798, BIVALVIA) FROM INDIVIDUAL TO POPULATION SCALE
}

\author{
MATHILDE MENOUD, ${ }^{1,2}$ SIMON VAN WYNSBERGE, ${ }^{1,3}$ GILLES LE MOULLAC, ${ }^{2}$ \\ PEVA LEVY, ${ }^{2}$ SERGE ANDRÉFOUËT, ${ }^{3}$ GEORGES REMOISSENET ${ }^{4}$ AND \\ NABILA GAERTNER-MAZOUNI ${ }^{1 *}$ \\ ${ }^{1}$ Université de la Polynésie Française, UMR-241 EIO, Laboratoire d'Excellence CORAIL, BP 6570, \\ Faa'a, Tahiti, French Polynesia; ${ }^{2}$ Ifremer, UMR 241 EIO, Laboratoire d'Excellence CORAIL, BP 7004, \\ 98719 Taravao, Tahiti, French Polynesia: ${ }^{3}$ Institut de Recherche pour le Développement, UMR 9220 \\ ENTROPIE (Institut de Recherche Pour le Développement, Université de la Réunion, Centre National de \\ la Recherche Scientifique), Laboratoire d'Excellence CORAIL, 101 Promenade Roger Laroque, BP A5, \\ 98848, Noumea, New-Caledonia; ${ }^{4}$ Direction des Ressources Marines et Minières, Fare Ute, Immeuble le \\ Caill, BP 20, Papeete, Tahiti, French Polynesia
}

\begin{abstract}
Monitoring gonad maturation for protandrous and functional hermaphrodite species such as the giant clam Tridacna maxima is difficult due to the juxtaposition and relative proportion of male and female tissues in the gonad [gonadal sex ratio (GSR)]. Here, the relevance of the widely used gonadosomatic index (GSI) as proxy of giant clam gonad maturation is tested with a large dataset $(n=265)$. Gonadosomatic index is compared with other indices, namely the proportion of the male part harboring spermatozoids, the proportion of empty oocyte follicles, the mean oocyte diameter, and the oocyte elongation. At gonad scale, high index variability highlighted partial spawning. At individual scale, male and female maturation proxies were contrasted, showing either asynchronous emissions of male and female gametes or contrasted spermatogenesis and oogenesis duration. The GSI was mostly driven by the number and diameter of oocytes and therefore it is recommended here as primary proxy for female maturity. Except for the oocyte elongation, all indices were affected by the GSR, which ruled out drawing conclusions at population scale. These results highlight the need for maturation stage proxies that are optimized for functional hermaphrodite species.
\end{abstract}

KEY WORDS: giant clam, marine bivalve, reproduction, spawn, Tatakoto atoll, histology, Tridacna maxima

\section{INTRODUCTION}

The reproduction of molluscan bivalves has been closely studied in the past decades to support management decisions (Byrne 1998, Beasley et al. 2000, Hold et al. 2013), pest control (Ram et al. 1996), and to enhance aquaculture farming (Joaquim et al. 2008). Past studies mostly attempted to establish methods for spawn induction (Gibbons \& Castagna 1984, Vélez et al. 1990, Mies \& Sumida 2012, Navneel \& Azam 2013), to characterize gamete release and spawning behavior (Jameson 1976, Marteil 1976, André \& Lindegarth 1995), to evidence seasonality in reproductive competence (e.g., Marteil 1960, Grant \& Tyler 1983, Beasley et al. 2000, Pouvreau et al. 2000), and to identify potential high reproductive areas (Williams \& Babcok 2010, Hold et al. 2013).

Gonad maturation can be used as a proxy of reproductive activity. Specifically, monitoring the ratio of immature versus ripe and spent gonads provides useful information on the spawning season (Ram et al. 1996, Beasley et al. 2000), whereas spatially structured sampling may help in the detection of reproductive success differences among sites and habitats (Hold et al. 2013).

In practice, gonad maturation can be assessed using a variety of tools. The simplest proxy of gonad maturation is the gonadosomatic index (GSI), usually defined as the ratio between gonad weight and flesh biomass (Shelley \& Southgate 1988, Pouvreau et al. 2000, Gagné et al. 2003). Shell height can also be used instead of flesh biomass (Williams \& Babcok 2010, Hold et al. 2013). The GSI assumes that the weight of ripe gonads is

*Corresponding author. E-mail: nabila.gaertner-mazouni@upf.pf DOI: $10.2983 / 035.035 .0107$ greater than immature and spent gonads. This was demonstrated for bivalves (Urban \& Riascos 2001) and other taxa as well (Rheman et al. 2002). Gonad maturation can also be apprehended through gamete shape, size, and stage of gametogenesis, using gonad biopsy (Braley 1984) and histology (Juhel et al. 2003, Popovic et al. 2013, Lacoste et al. 2014). For instance, female maturity has usually been described according to oocyte diameter and perimeter (Grant \& Tyler 1983, Popovic et al. 2013), whereas male maturity has been determined using semiquantitative indices related to spermatogenesis stages (Jameson 1976, McKoy 1980, Richard 1982, Nash et al. 1988).

Proxies of gonad maturation have been validated for short life species with a protandrous life cycle such as the Cockle Clinocardium nuttallii (Conrad, 1837) (Gallucci \& Gallucci 1982), the silverlip pearl oyster Pinctada maxima (Jameson, 1901) (Rose et al. 1990), the European oyster Ostrea edulis (Linnaeus, 1758) (Marteil 1976), and the warty venus Venus verrucosa (Linnaeus, 1758) (Popovic et al. 2013). The determination of a reliable proxy for functional hermaphrodite species is, however, still lacking to date. For the functional hermaphrodite Pectinidae, Barber and Blake (2006) reviewed macro- and microscopic indices of gonad maturity. They concluded that the most common methods were gonad visual examination [Mason (1958) for Pecten maximus (Linnaeus, 1758)] and measurement of mean oocyte diameter [for Argopecten irradians (Lamarck, 1819) (Sastry 1970, Barber \& Blake 1981, Barber \& Blake 1983, Barber 1984)]. These functional hermaphrodite species, however, have clearly separated male and female tissues in the gonad, and the reported indices were only suitable for unisexual tissues. Nash et al. (1988) studied gonad maturation of the giant clam Tridacna gigas (Linnaeus, 1758) 
(subfamily Tridacninae) by qualitatively characterizing the maturity stages of male and female tissues. They highlighted that (1) male and female tissues were mixed and juxtaposed in the gonad, (2) spermatogenesis and oogenesis were not synchronous, and (3) maturation was not homogeneous at intragonad scale. These observations show that there is no meaningful gonad maturation index that is robust in all situations. Moreover, the progressive proliferation of female tissues against male tissues in the course of the life of a protandrous individual may interfere with maturity stages and thus may complicate the analyses.

The giant clam is a long-lived species with continuous growth over its lifetime that obeys a Von Bertalanfy growth curve (Richard 1982, Smith 2011). The maximum reported sizes range from 33 to $137 \mathrm{~cm}$ for, respectively, the small species Tridacna maxima (Röding, 1798) (Lewis et al. 1988) and the large Tridacna gigas (Griffiths \& Klumpp 1996), the latter being the largest bivalve species on the planet. Giant clams differ from other bivalves as most of the carbon necessary for growth and reproduction comes from their symbiotic zooxanthellae (Griffiths \& Klumpp 1996). The giant clam T. maxima is a protandrous hermaphrodite (Jameson 1976). It first matures as male between 5-7-13 cm (Richard 1982), then it has both sexes during most of their life. Very old individuals usually harbor female tissues only (Richard 1982). During the functional hermaphroditism phase of their life cycle, clams can spawn successively spermatozoa and eggs, with a 30-min time gap to avoid self-fertilization (McKoy 1980, Mies \& Sumida 2012). This functional phase is the focus of this study; therefore, giant clams are considered here as functional hermaphrodites.

To date, giant clam gonad maturation has only been assessed on the basis of qualitative and semiquantitative proxies of maturation stages (Nash et al. 1988), and the robustness of these proxies has yet to be analytically verified taking into account the giant clam's specific traits. In this study, a panel of quantitative proxies of gonad maturity for Tridacna maxima is first defined. Then, their robustness against the giant clam's particular reproductive features is assessed. Specific attention is paid to the relative proportion of female versus male tissues in the gonad, which is referred to hereafter as the gonadal sex ratio (GSR). For this, the variability of indices at gonad scale (i.e., intraindividual variability) is characterized. Then, at individual scale, the relationship between the tested proxies of maturity (i.e., male, female, and GSI) and GSR is assessed. Finally, considering the observed variability at intra and interindividual scale, as well as practical measurements and monitoring issues, the relevance of these indices as proxies of gonad maturity at population scale is assessed and discussed.

\section{MATERIALS AND METHODS}

\section{Ethics Statement}

Giant clam collections for this study were authorized by French Polynesia Ministerial Order no. 2850/MRM.

\section{Sample Collection}

Giant clam samples were collected at Tatakoto atoll $\left(17.3^{\circ} \mathrm{S}\right.$, $\left.138.4^{\circ} \mathrm{W}\right)$, in the Tuamotu Archipelago in French Polynesia (Fig. 1A). In November 2012, 25-45 specimens were collected from nine sites distributed throughout the lagoon (Fig. 1B). A larger number of samples were collected in the eastern enclosed part of the lagoon (45 and 44 clams for stations 11 and 14, respectively) because giant clams are more abundant in this area (Gilbert et al. 2006, Andréfouët et al. 2013).

For each giant clam, the maximum shell size and the biomass of the wet flesh were measured with the byssus still attached. The byssus is made of filaments secreted by the clam to attach itself to a hard substratum. Wet flesh biomass without byssus was computed using a previous relation between flesh weights with and without byssus established from 85 individuals from the same atoll (Fig. 2). Gonads (including the digestive gland) were retrieved, weighed to the nearest $0.1 \mathrm{~g}$, and fixed using a $10 \%$ formalin (i.e., $4 \%$ formaldehyde) solution.

\section{Histological Treatment}

Histological treatments followed Howard and Smith (1983). The gonad samples were dehydrated by successive bathing in $70 \%, 80 \%, 95 \%$, and $100 \%$ ethanol before inclusion in paraffin blocks (with Leica ASP300 and Leica EG1150 machines). Each gonad sample was sectioned across its longitudinal median axis using a microtome Leica RM2135 (5- $\mu$ m sections). All sections were stained with eosin and hematoxylin for microscope observation (with Leica AUTOSTAINER XL).

\section{GSR and Gonad Maturation}

Five proxies of maturity stage were tested in this study. First, the GSI was defined by the ratio of gonad wet weight ( $\left.W_{\text {gonad }}\right)$ to the flesh biomass without byssus ( $W_{\text {biomass }}$ ) (Eq. 1). Because gonadal tissues cannot be easily isolated from the digestive gland, $W_{\text {gonad }}$ included both the weight of the gonad and the weight of the digestive gland.

$$
\mathrm{GSI}=\frac{W_{\text {gonad }}}{W_{\text {biomass }}}
$$

Second, for each histological gonad section with mature tissues and depending on the slide area, up to three $1310 \times$ $980 \mu \mathrm{m}$ pictures $(\times 100$ microscope magnifying $)$ were taken in alignment for each of the anterior, posterior, and middle gonad regions. This provided up to nine picture snapshots of the gonad. Pictures were taken using the software Leica Application Suite 3.7.0. For each picture, the GSR (see below) and the maturity stages of both male and female tissues were measured. For each index, a gonad-scale mean value was computed by averaging the (up to) nine values.

In each picture, the GSR was semiquantitatively defined as the proportion of male tissues versus female tissues using the legend keys presented in Table 1 and illustrated in Figure 3A-E.

The male tissue maturity stage (referred to hereafter as "SPZ" index) was characterized semiquantitatively by the proportion of male tissues with spermatozoa compared with male tissues without spermatozoa (Table 1, Fig. 3F-H).

The female tissue maturity stage was characterized by the proportion of empty oocyte follicles (referred to hereafter as "EOF" index, Fig. 4A, B).

For the female part, maturity stages were also characterized at individual scale using oocyte size and shape, as presented by Grant and Tyler (1983). The longest and shortest diameters for a maximum of 30 oocytes were measured along the longitudinal axis of the gonad section ( $\times 200$ microscope magnification). Measurements were taken only for oocytes with a visible nucleolus, as recommended by Lango-Reynoso et al. (2000) (Fig. 4). 

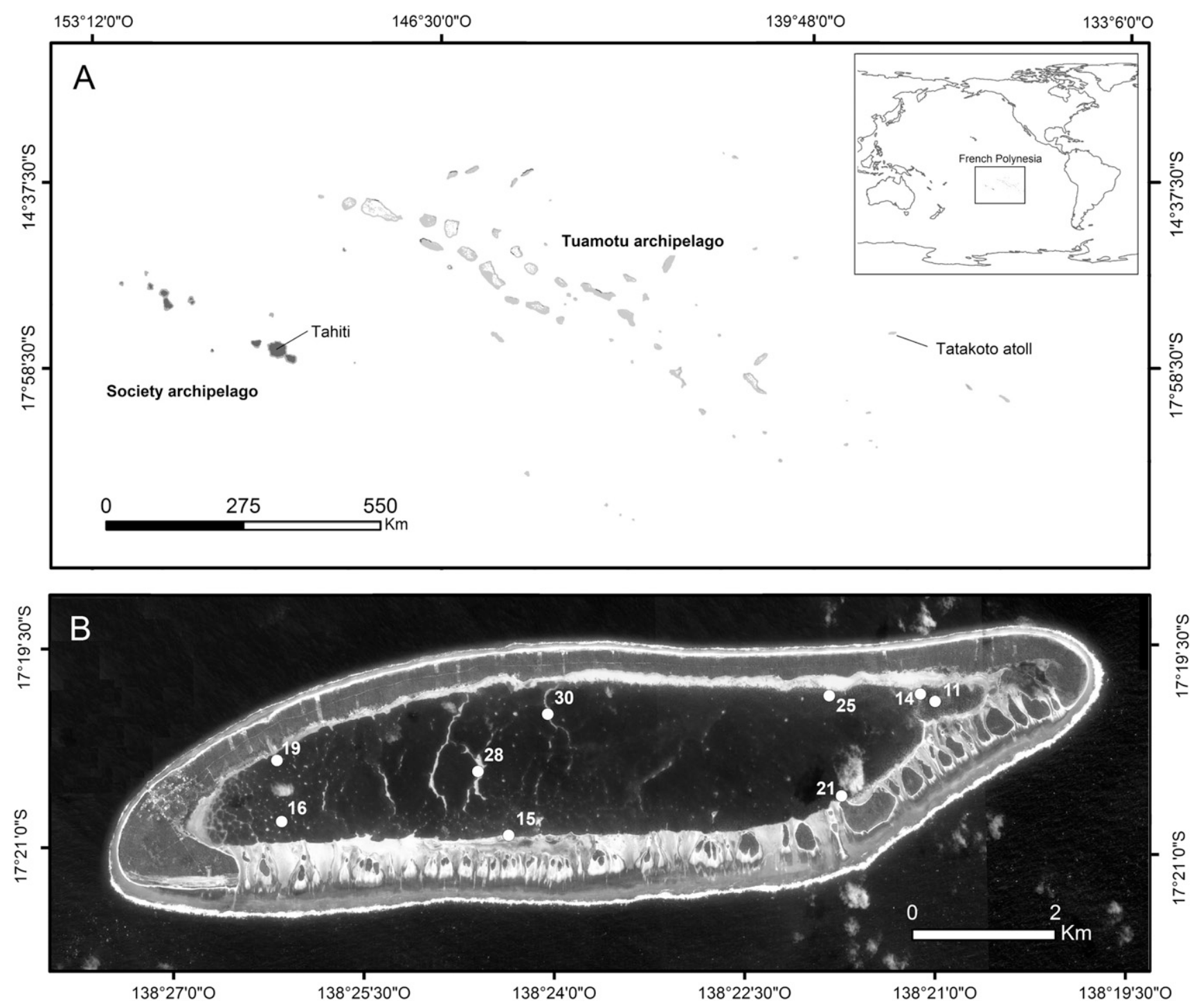

Figure 1. (A) Location of Tatakoto in French Polynesia and (B) map of the nine stations located in the lagoon of the atoll. Numbers refer to the name of stations.

Then, two female maturation proxies were computed: the oocyte mean diameter (referred to hereafter as " $\varnothing$ " index, as the mean between the longer and shorter oocyte diameters) and the oocyte elongation (referred to hereafter as the " $1 / \mathrm{L}$ " ratio, as the ratio between the shorter and longer oocyte diameters). The oocyte $1 / \mathrm{L}$ ratio can be a relevant maturity index, because oocytes are elongated at the beginning of their development and become rounder during their growth (Norton \& Jones 1992).

\section{Characterizing the Variability of Maturation Indices}

The variability of maturation indices was characterized at three different scales.

At gonad scale, the spatial maturity stage autocorrelation was investigated by measuring the correlation between a $9 \times 9$ weighted neighbor distance matrix and the $9 \times 9$ distance matrix that summarized the maturity stage differences computed for each pair of pictures. For the weighted neighbor matrix, the weights are set to 1 and 1.5 for pictures, respectively, separated by a horizontal/vertical path, and a diagonal path. The "mantel. rtest" function of "ade4" package in R 3.1.0 was used to test the correlation between the two matrices.

At the scale of an individual, the correlation of maturity indices to GSR (i.e., the mean value of all pictures) was tested by modeling the maturity indices as a smooth function of GSR using the "gam" function of package "mgcv" in R 3.1.0. The significance of the relationship was tested on the basis of the "summary" function. The correlation between each maturity index (i.e., GSI, SPZ, Ø, 1/L, and EOF) was also tested, using a nonparametric Kendall correlation test. Because GSI could be influenced by both female and male tissues, and by the relative proportion of female versus male tissues in the gonad, a generalized linear model determined which variables related to male maturity, female maturity, or GSR most influenced GSI. The "glm" function of "stats" package in R 3.1.0 was used. The start model included all parameters (i.e., GSR, SPZ, Ø, 1/L ratio, and EOF), and the significance of each parameter was assessed using the $P$ value given by the "summary" function. The model was rerun without the nonsignificant terms, and the Akaike Information Criterion (AIC) was used to select the best model. 


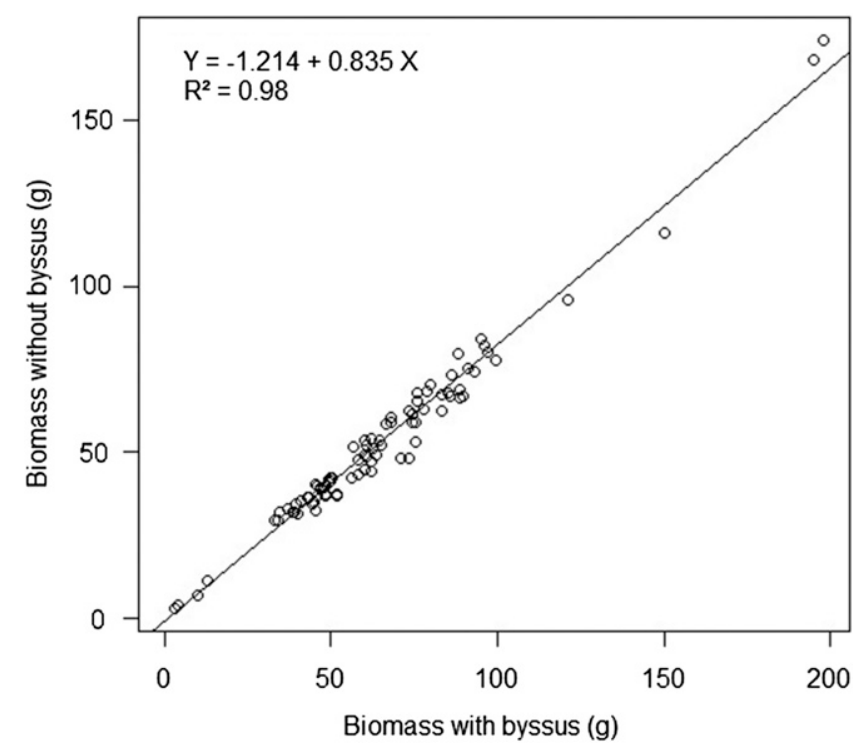

Figure 2. Relationship between biomass measured without and with byssus established from 85 specimens of various sizes.

Finally, to consider the variability at population scale, the mean values of all indices and their distributions were compared between the nine stations. The "boxplot" function of package "graphics" in R 3.1.0 was used. Considering the small size, isolation, and lagoon enclosure of the Tatakoto atoll (Fig. 1), only a single population was considered for the entire lagoon. The comparison of maturity indices between stations provided a basis for measuring the inter- and intrastation variabilities, and therefore whether a restricted number of stations could be representative of the entire lagoon.

\section{RESULTS}

\section{Intra-Gonadal Variability of Maturation Stages}

At gonad scale, the SPZ and EOF indices were heterogeneous, with pairwise differences between pictures covering the entire range of values ( $0-2$ and $0-1$ respectively, Fig. 5). In both cases, however, the frequency of paired distances was higher for low pairwise differences. This suggests that the nine pictures frequently provided coherent values for SPZ and EOF indices at gonad scale. Spatial autocorrelation Mantel test $P$ values at intragonad scale ranged from 0.02 to 1 , and were significant for a small number of giant clams (Table 2). This confirmed that little spatial variations occurred for these two indices.

\section{Inter-Individual Variability of Maturation Stages}

Male tissue in gonads could be found for specimens as small as $2 \mathrm{~cm}$. Mature male tissue was found for specimens as small as $2.5 \mathrm{~cm}$. Rare and patchy distributed oocytes were recorded for some 5-cm-long giant clams, with progressive proliferation of female tissue when giant clams grew larger. The GSR index was therefore a slightly increasing function of the maximum shell length (Fig. 6A), reflecting the progressive shift from dominant male tissues toward dominant female tissues.

All indices but the oocyte $1 / \mathrm{L}$ ratio were significantly influenced by GSR (Table 3). In particular, small $\varnothing$ values and highly variable EOF values corresponded to gonads dominated by the male parts (i.e., low GSR, Fig. 6D, F), highlighting a low robustness of these indices to GSR. The GSI was more robust, with only $3.5 \%$ of its deviance explained by GSR (Table 3), but the relationship was significant with low values of GSI for gonads dominated by the male part (Fig. 6B).

Gonadosomatic Index was positively correlated with $\varnothing$, but negatively correlated with SPZ and EOF (Table 4). This finding suggested that GSI essentially reflects the oocyte weight. Similarly, the simple model which expressed GSI as a function of $\varnothing$ and EOF was selected because it provided only a negligible increase of AIC compared with the start model (Table 5). This reduced model suggested that GSI was essentially driven by the female part of the gonad, with high GSI values when oocyte follicles were filled with large oocytes.

No relationships could be evidenced between male and female maturity stages except between SPZ and EOF $(\tau=-0.14, P<$ 0.01 , Table 4). In contrast, it was found that various indices of female maturity were in agreement with $\varnothing$ significantly correlated with the oocyte $1 / \mathrm{L}$ ratio $(\tau=0.17, P<0.01$, Table 2$)$ and $\mathrm{EOF}$ ( $\tau=-0.12, P<0.05$, Table 4$)$.

\section{Maturity Stages at Population Scale}

The GSR distributions and mean values, as well as maturity indices for every station, are presented in Figure 7. Contrasted values of GSR were observed between stations (Fig. 7A). Giant

TABLE 1.

Description of GSR and SPZ.

\begin{tabular}{|c|c|c|c|}
\hline Index & Value & Name & Description \\
\hline \multirow[t]{5}{*}{ GSR } & 1 & Male & Only male gonadic tissue presents (Fig. 3A) \\
\hline & 2 & Male dominant & $\begin{array}{l}\text { Male and female gonadic tissues present and male tissue surface area is } \\
\text { dominant (Fig. 3B) }\end{array}$ \\
\hline & 3 & Male and female & Male and female gonadic tissues present with equivalent surface areas (Fig. 3C) \\
\hline & 4 & Female dominant & $\begin{array}{l}\text { Male and female gonadic tissues present and female tissue surface area is } \\
\text { dominant (Fig. 3D) }\end{array}$ \\
\hline & 5 & Female & Only female gonadic tissue presents (Fig. 3E) \\
\hline \multirow[t]{3}{*}{ SPZ } & 1 & Beginning of spermatogenesis & No fully formed spermatozoa (Fig. 3F) \\
\hline & 2 & Development & $\begin{array}{l}\text { Fully formed spermatozoa that represent less than half of the male tissue } \\
\text { surface area (Fig. } 3 \mathrm{G} \text { ) }\end{array}$ \\
\hline & 3 & End of spermatogenesis & $\begin{array}{l}\text { Fully formed spermatozoa that represent more than half of the male tissue } \\
\text { surface area (Fig. } 3 \mathrm{H})\end{array}$ \\
\hline
\end{tabular}



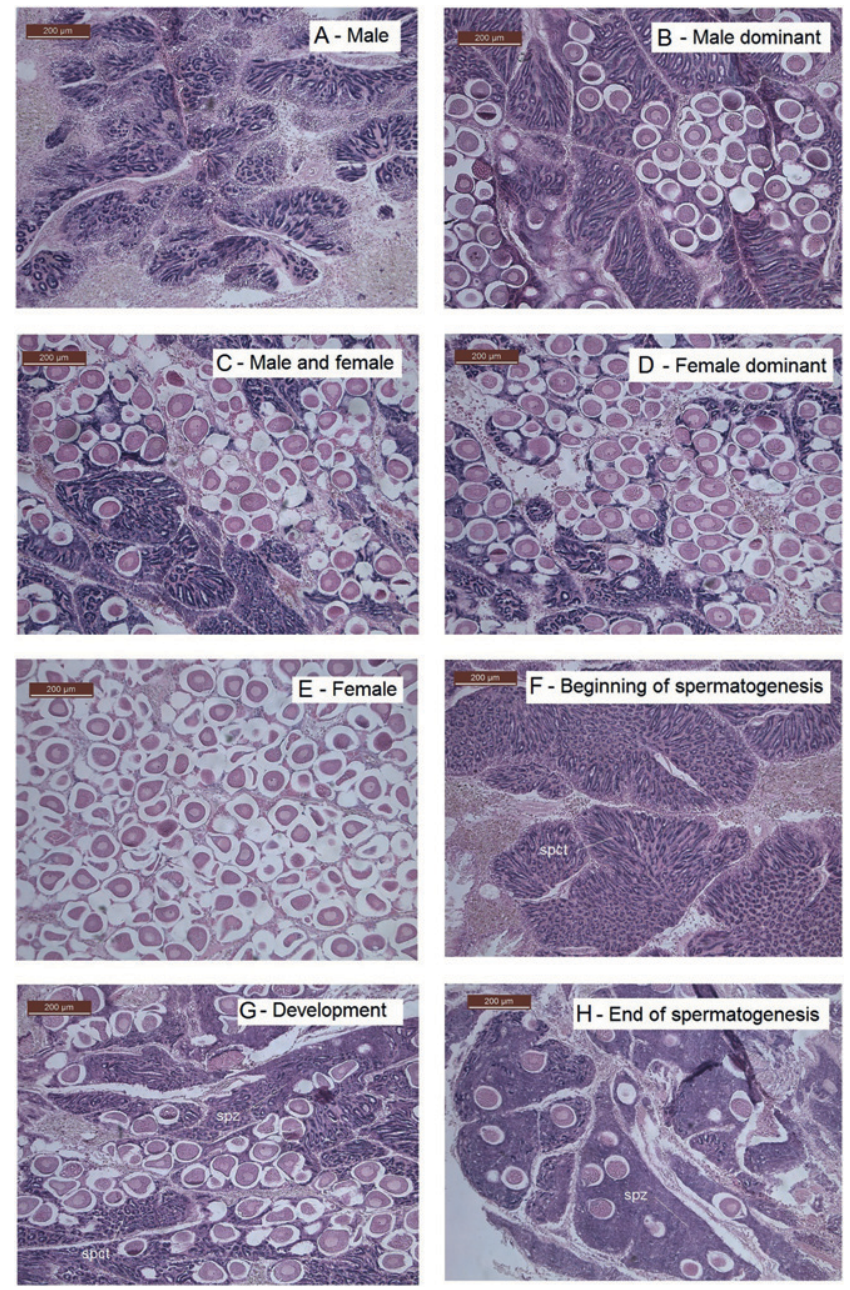

Figure 3. (A-E) Visualization of GSR stages and (F-H) SPZ used in this study. Spct $=$ spermatocytes; $\mathrm{Spz}=$ spermatozoa.

clams mainly dominated by the male tissues occurred at stations 21 and 28, whereas giant clams dominated by the female tissues occurred at station 19. This resulted in high estimates of the proportion of spermatozoids (SPZ, Fig. 7C), small oocytes (Ø, Fig. 7D), high variability in oocyte shape $(1 / \mathrm{L}$ oocyte ratio, Fig. $7 \mathrm{E})$, and finally a high proportion of empty follicles (EOF, Fig. 7F), especially for station 21. The weight of the gonad was low relative to the body weight for this station (GSI, Fig. 7B).

\section{DISCUSSION}

\section{GSR over a Lifetime}

Previous studies on giant clam reproduction classified individuals as immature, male, female, and hermaphrodite (Nash et al. 1988). Here, these different states were found at various locations within a single gonad. This confirmed that change from one state to another is a continuous process, with progressive oocyte proliferation in the gonad when giant clams grow larger (Fig. 6A). The interindividual variability was high, with only $40.5 \%$ of the GSR variability explained by size. This suggests that other complex processes, possibly environmentally driven processes, control sex determination. Sex determination of bivalves can be influenced by a variety of factors (Yusa 2007), including genetic determination, temperature and food stresses (ChavezVillalba et al. 2011), environmental factors (temperature, dissolved oxygen, chlorophyll, salinity, etc.; Marteil 1960, Cano et al. 1997), and associations with conspecifics (Collin 1995). As such, a complete model of maturation across time and scales for the functional hermaphrodite giant clams requires substantial new ecophysiological investigations.

The functional hermaphrodite phase of Tridacna maxima spans most of the giant clam's lifetime, with the male sensu stricto (i.e., without any oocyte observed) phase usually found only for 1- to 3-y-old $(2-7 \mathrm{~cm})$ individuals (Fig. 6A). These results have implications for fishery management. For instance, the $12 \mathrm{~cm}-$ minimum size limit for capture in French Polynesia appears suitable to maintain production of both male and female gametes and a balanced sex ratio. Male tissues were present in the gonad of giant clams no longer than $2 \mathrm{~cm}$. Conversely, male tissues also remained present (albeit in small proportion) even for the largest individuals sampled in this study $(20 \mathrm{~cm})$. This is in contrast with the findings of Richard (1982) from Takapoto atoll where clams longer than $15 \mathrm{~cm}$ only yielded female tissue. This atoll is famous for the dwarfism of its bivalves (Zanini 1994), and a 15-cm clam at Takapoto is probably much older than a clam of similar size at Tatakoto.

\section{Robustness of Maturity Stages to GSR}

The functional hermaphroditism of giant clams is a serious challenge for establishing relevant and accurate maturity stage indices. The progressive increase of female tissues in the gonad when giant clams grow larger biased the GSI and almost all proxies of female maturation tested in this study. Specifically, whereas oocytes could be recorded for giant clams as small as $5 \mathrm{~cm}$, gonads dominated by male tissues yielded underestimated values of oocyte diameters and highly variable EOF (Figs. 6D, $\mathrm{F}$ and $7 \mathrm{D}, \mathrm{F})$.

It is uncertain whether the positive relationship between $\varnothing$ and GSR was induced by physiology (the larger the clam, the larger the oocytes), reproductive competence (oocyte present in low GSR gonads are not mature), or oocyte measurement errors (small oocytes were more easily missed when surrounded by larger ones). Nevertheless, this study suggests that caution is necessary when using $\varnothing$ as proxy of female maturation from a pool of giant clams of various sizes and at various GSR stages. Similarly, the EOF index was highly variable for male tissuedominated gonads (GSR < 1.5) in which scarce and patchy oocyte follicles were too few to adequately estimate female maturity.
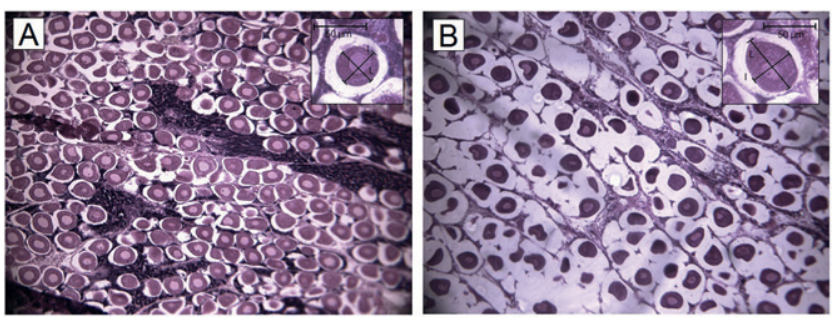

Figure 4. Illustrative examples of criteria used to define the female maturation stages. (A) Female part with most of the oocyte follicles filled and circular oocytes $(\mathrm{I} / \mathrm{L}$ ratio $=0.989),(B)$ female part with some of oocyte follicles empty and elongated oocytes $(\mathrm{I} / \mathrm{L}$ ratio $=0.711)$. 


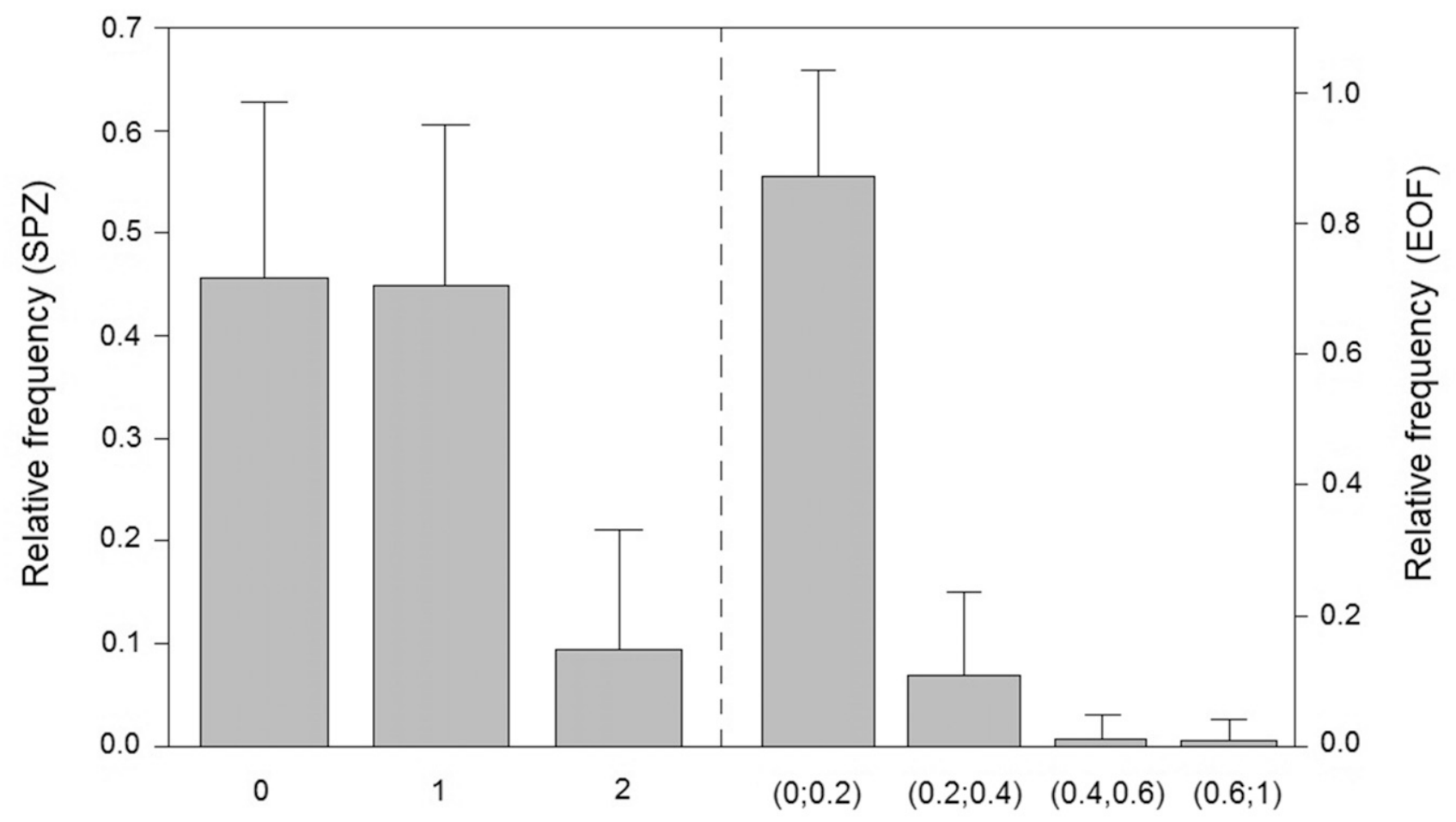

Paired SPZ distances

Paired EOF distances

Figure 5. Histogram of paired SPZ and EOF distances measured between pictures inside a gonad.

Our attempts to accurately characterize maturity stages were challenged by a number of factors. First, confusion between stages could arise when massive spawn drained all the spermatozoids from gonads dominated by the female part. In this case, it is difficult to differentiate a spawned hermaphrodite gonad from a gonad harboring female tissues only. It is worth pointing out that fully female gonads are rare (none were found in this study) and only found for very old (or very large) individuals (Richard 1982). This fact helps in differentiating the two stages. Second, confusion may also arise when tissues are not fixed properly. Fixative (formalin) seldom penetrates to the center of large gonad samples. Unfixed gonad tissue should be discarded, because it is uncertain whether empty follicles or absence of spermatozoids in a gonad result from a spawn event or from the collapse of the structure when cutting the gonad. Alternatively, fixative can be directly injected into the sample with a syringe (Etheridge 1996) and this protocol should be preferentially applied.

\section{Heterogeneity of Maturity Stages at Gonad Scale}

Gonad scale maturation stages were highly variable in this study (Fig. 5). In other words, one individual could display several maturity stages depending on the gonad area. This suggests that for giant clams, either a partial or a complete draining of the gametes may occur during a spawning event. The same patterns were observed for the pearl oyster Pinctada margaritifera (Linnaeus, 1758) at Takapoto atoll (Pouvreau et al. 2000). Few studies have thus far investigated the variability of maturity stages at intragonadal scale for bivalves. To our knowledge, only Nash et al. (1988) and Delgado and PérezCamacho (2007) have studied maturation stages inside the gonads of the giant clam Tridacna gigas and the clam Ruditapes philippinarum (Adams \& Reeve, 1850), respectively. Both studies concluded that a high variability of maturation stages occurred. The latter study showed during laboratory experiments that three different reproductive phases could frequently occur within the same individual.

Partial spawning, in addition to rapid and always active gametogenesis (<28 days for Crassostrea sp., Wintermyer \& Cooper 2007), may explain the continuous reproductive competence and low spawning seasonality reported for most tropical bivalves (Lefort \& Clavier 1994, Pouvreau et al. 2000, Urban 2000). For the giant clam, thus far, the spawning

TABLE 2.

Results of Mantel tests for spatial auto-correlation between pictures at intragonad scale.

\begin{tabular}{lrcccc}
\hline \hline Maturity index & $\boldsymbol{n}$ & $\mathbf{2 5 \%}$ Quantile of $\boldsymbol{P}$ values & Median of $\boldsymbol{P}$ values & $\mathbf{7 5 \%}$ Quantile of $\boldsymbol{P}$ values & Proportion of tests significant (\%) \\
\hline SPZ & 102 & 0.11 & 0.39 & 0.77 \\
EOF & 60 & 0.20 & 0.51 & 0.81 \\
\hline
\end{tabular}

$n$ is the number of specimens for which a test could be applied. Tests are considered significant when $P<0.05$. 

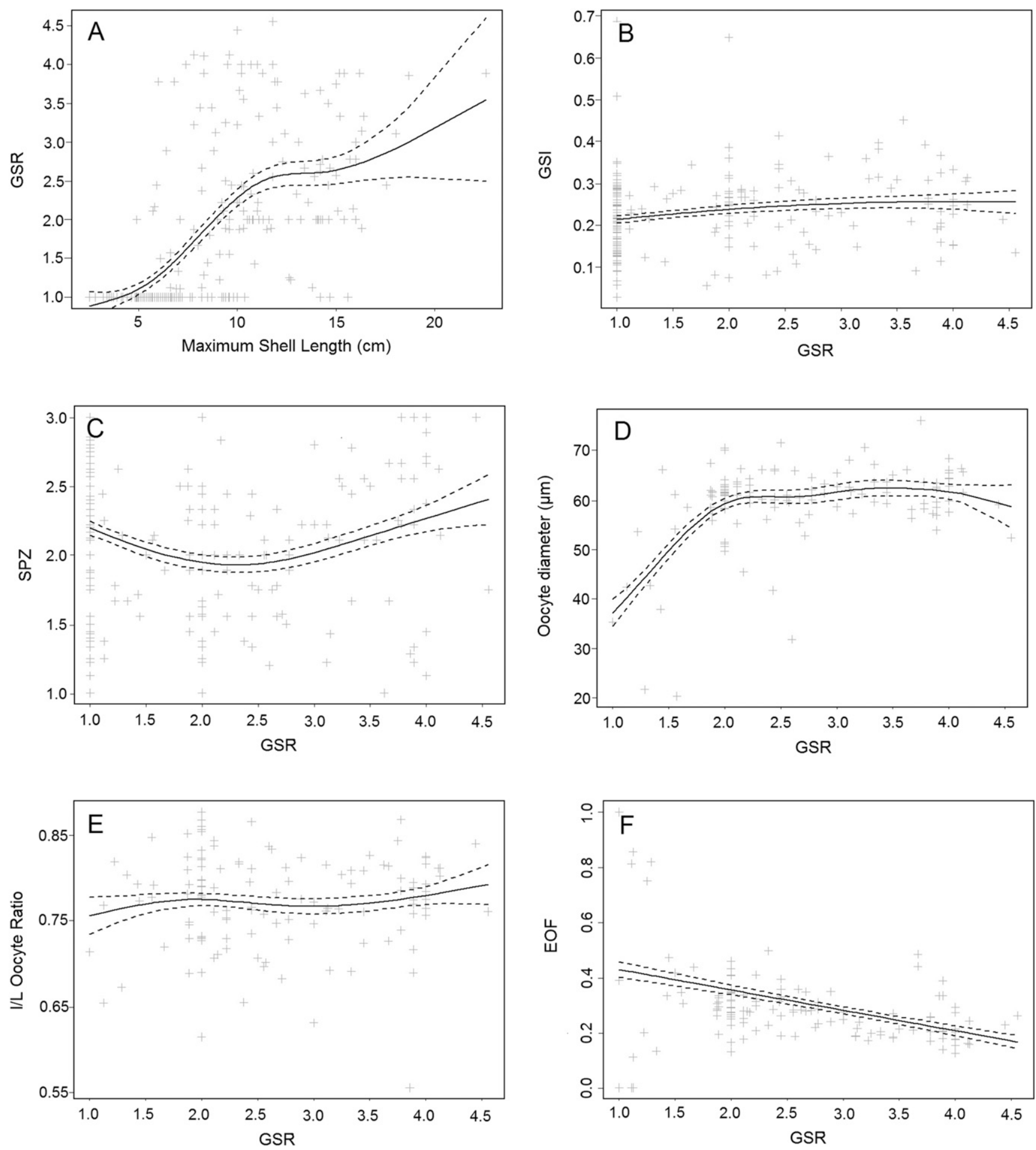

Figure 6. Smooth function which best fits the relationship between (A) GSR and maximum shell size (SIZE) and between GSR and (B) GSI, (C) SPZ, (D) oocyte diameter, (E) oocyte $\mathrm{l} / \mathrm{L}$ ratio, and (F) EOF. Dashed lines represent the standard error.

periods and their triggers in the wild have not yet been identified (Bell \& Pernetta 1988, Braley 1988, Nash et al. 1988, Soo \& Todd 2014). In fact, it has been rather argued that the low temperature contrast between seasons in the tropics induces continuous gametogenesis (Pouvreau et al. 2000). The high heterogeneity of maturity stages in gonads found in the present study suggests that only partial spawning events have occurred before the gonad sampling.
Unfortunately, this study cannot shed light on seasonal periodicity and temporal variation, because all individuals were sampled during a single period (in November 2012). Further investigations should assess gonad maturity variability through time. Spatially, except for few stations where unusual values of GSR were measured (e.g., station 21), maturity indices were congruent throughout Tatakoto lagoon. This suggests that the sampling effort for the 
TABLE 3.

Results from the gam models used to test the relationship between maturity indices and GSR, and between GSI and shell size (SIZE).

\begin{tabular}{lccrc}
\hline \hline Model tested & edf & $\boldsymbol{n}$ & $\boldsymbol{P}$ value & Deviance explained (\%) \\
\hline GSI $\sim$ SIZE & 4.04 & 224 & $<0.001$ & 40.5 \\
GSI $\sim$ GSR & 1.53 & 181 & 0.028 & 3.5 \\
SPZ $\sim$ GSR & 2.33 & 224 & 0.002 & 6.8 \\
$\varnothing \sim$ GSR & 4.17 & 124 & $<0.001$ & 30.2 \\
l/L $\sim$ GSR & 2.56 & 124 & 0.565 & 2.5 \\
EOF $\sim$ GSR & 1 & 135 & $<0.001$ & 6.4 \\
\hline
\end{tabular}

$\varnothing=$ mean oocyte diameter. $\sim$ is read as "modeled as a function of".

monitoring of gonad maturation could be spatially limited with a low number of stations.

\section{Phases between Male and Female Maturity Stages}

The male and female maturity stages could not be related in this study. This may be partly due to the semiquantitative versus quantitative nature of the indices established for male and female maturity, respectively. A meaningful comparison between SPZ and $\varnothing$ could be made by translating the absolute oocyte diameters values into semiquantitative values [see Lango-Reynoso et al. (2000) for an example with the Pacific oyster Crassostrea gigas (Thunberg, 1793)]. Similar differences between male and female maturity stages were also found for Tridacna gigas on the basis of semiquantitative indices only (Nash et al. 1988), highlighting a nonsynchrony between spermatogenesis and oogenesis.

A nonsynchrony between male and female maturation stages can effectively occur if spermatogenesis and oogenesis durations differ. Wintermyer and Cooper (2007) provided a similar duration required for spermatogenesis and oogenesis (28 days) for Crassostrea virginica (Gmelin, 1791). Unfortunately, similar estimations are not yet available for the giant clam functional hermaphrodite. The nonsynchronic spawning of male versus female gametes can, however, also explain the nonsynchronic maturation stages. Most studies in experimental facilities describing the spawning behavior of Tridacna maxima reported emission of male gametes followed by emission of female gametes 15-30-60 min later (McKoy 1980, Garen 2003, Mies \& Sumida 2012), but it seems likely that the female gamete spawn is not systematic. In the preliminary experiments of the present study, only male gamete emissions were observed for several hermaphrodite individuals (SVW observations).

\section{The Use of GSI as Proxy of Maturation Stage}

The GSI, as well as other related indices (e.g., Relative gonad to shell height, Hold et al. 2013), has been widely used for characterizing the gonad maturation of bivalves (Shelley \& Southgate 1988, Gagné et al. 2003). The gonad size is also commonly considered as a proxy of reproductive activity by local fishermen at Tatakoto atoll (SVW observations). In this study, it is highlighted that for Tridacna maxima, GSI is mainly influenced by the number and size of the oocytes, and does not follow the patterns of male maturity.

This has profound implications for future research on the giant clam's reproduction. First, giant clam studies that concluded on
TABLE 4.

Kendall's $\tau$ for correlation test between all the indices studied.

\begin{tabular}{lcccc}
\hline \hline & & \multicolumn{3}{c}{ Oocyte } \\
& SPZ & \multicolumn{1}{c}{$\varnothing$} & 1/L ratio & EOF \\
\hline GSI & $-0.15^{* *}$ & $0.24^{* * *}$ & 0.10 & $-0.27^{* * *}$ \\
SPZ & & 0.07 & 0.03 & $-0.14^{* *}$ \\
$\varnothing$ & & & $0.17^{* *}$ & $-0.12^{*}$ \\
Oocyte 1/L ratio & & & & 0.00 \\
\hline
\end{tabular}

$\varnothing=$ mean oocyte diameter.

Stars indicate significant tests $(* * * P<0.001, * * P<0.01, * P<0.05)$.

male and female maturation stages using GSI should be reconsidered (Shelley \& Southgate 1988). Second, because oocyte diameter and the proportion of oocyte empty follicles explained more than $54 \%$ of the GSI variability, GSI can be used as a first proxy of female maturity when no histological treatment can be performed.

In addition to the relationship between GSI and the female maturity stage, GSI also presents a number of practical advantages. First, GSI measurements are quick and inexpensive to perform compared with histological treatments and oocyte measurements. Second, GSI is calculated from the flesh biomass and the gonad weight, which are both quantitative measurements independent of any arbitrary decision when defining maturity stages. According to the present study, GSI is relatively robust to GSR compared with other indices. Finally, unlike gonad sections that are often performed in an arbitrary area of the gonad (usually the middle), GSI integrates information on maturity stages for the entire gonad. This is particularly relevant considering the intragonadal heterogeneity of the maturity stage.

\section{Conclusion and Recommendations for Future Research}

The present study is a methodological gap-filling step toward a better characterization of the reproduction of functional hermaphrodite bivalves. The asynchronous maturity of male and female tissues suggested by Nash et al. (1988) for Tridacna gigas is confirmed for Tridacna maxima. High heterogeneity of maturity stages at intragonadal scale is also highlighted. It is shown that the coexistence of male and female tissues in the gonad bias most maturity stage proxies used for other bivalves, which calls for an optimized protocol. Specifically, GSI and proxies for female maturity (oocyte diameter, EOF) were more accurate after female tissues had spread throughout the gonad, which is usually achieved for a shell length of 12-14 cm.

Future research should focus on characterizing the temporal (including seasonal) fluctuations of giant clam maturity stages

TABLE 5.

Generalized Linear Models tested to explain GSI values.

\begin{tabular}{lccc}
\hline \hline \multicolumn{1}{c}{ Model tested } & AIC & $\begin{array}{c}\text { Significant } \\
\text { variables }\end{array}$ & $\begin{array}{c}\text { Residual } \\
\text { deviance }\end{array}$ \\
\hline $\mathrm{GSI} \sim \mathrm{GSR}+\mathrm{SPZ}+\varnothing+\mathrm{EOF}+1 / \mathrm{L}$ & -226.4 & $\varnothing^{*} ; \mathrm{EOF}^{* *}$ & 0.43 \\
$\mathrm{GSI} \sim \varnothing+\mathrm{EOF}$ & -225.8 & $\varnothing^{*} ; \mathrm{EOF}^{*}$ & 0.46 \\
\hline
\end{tabular}

$\varnothing=$ mean oocyte diameter. $\sim$ is read as "modeled as a function of". Stars indicate significant tests $(* * P<0.01, * P<0.05)$. 


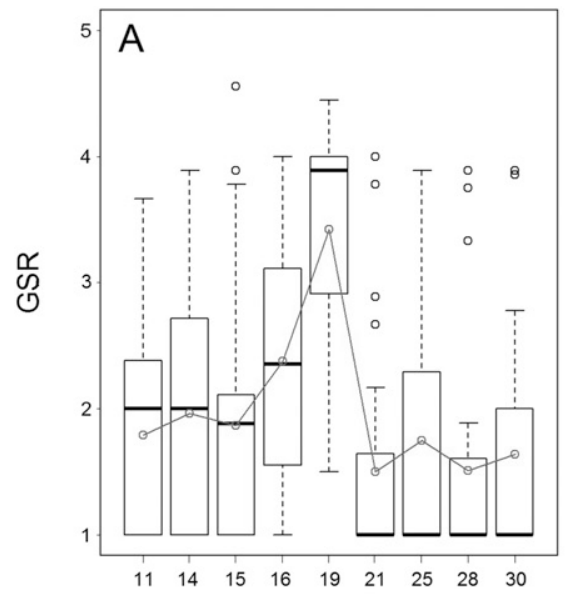

Stations

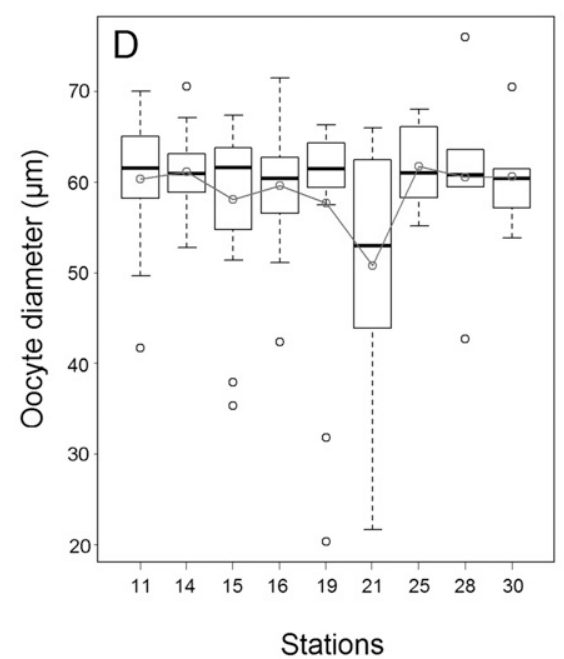

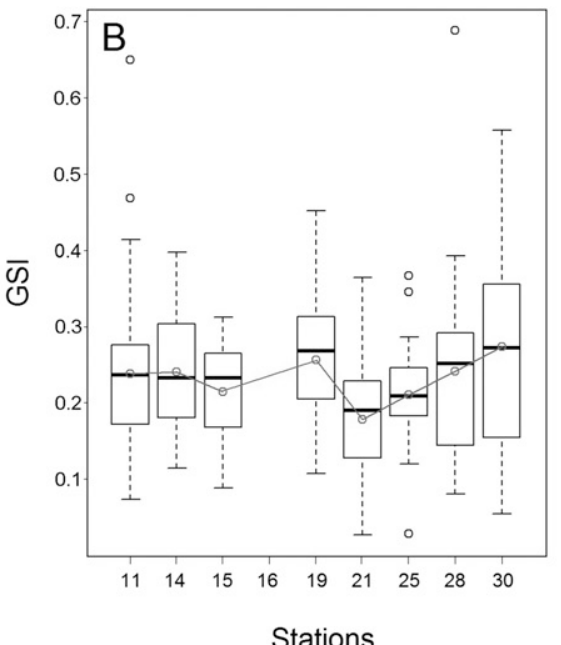
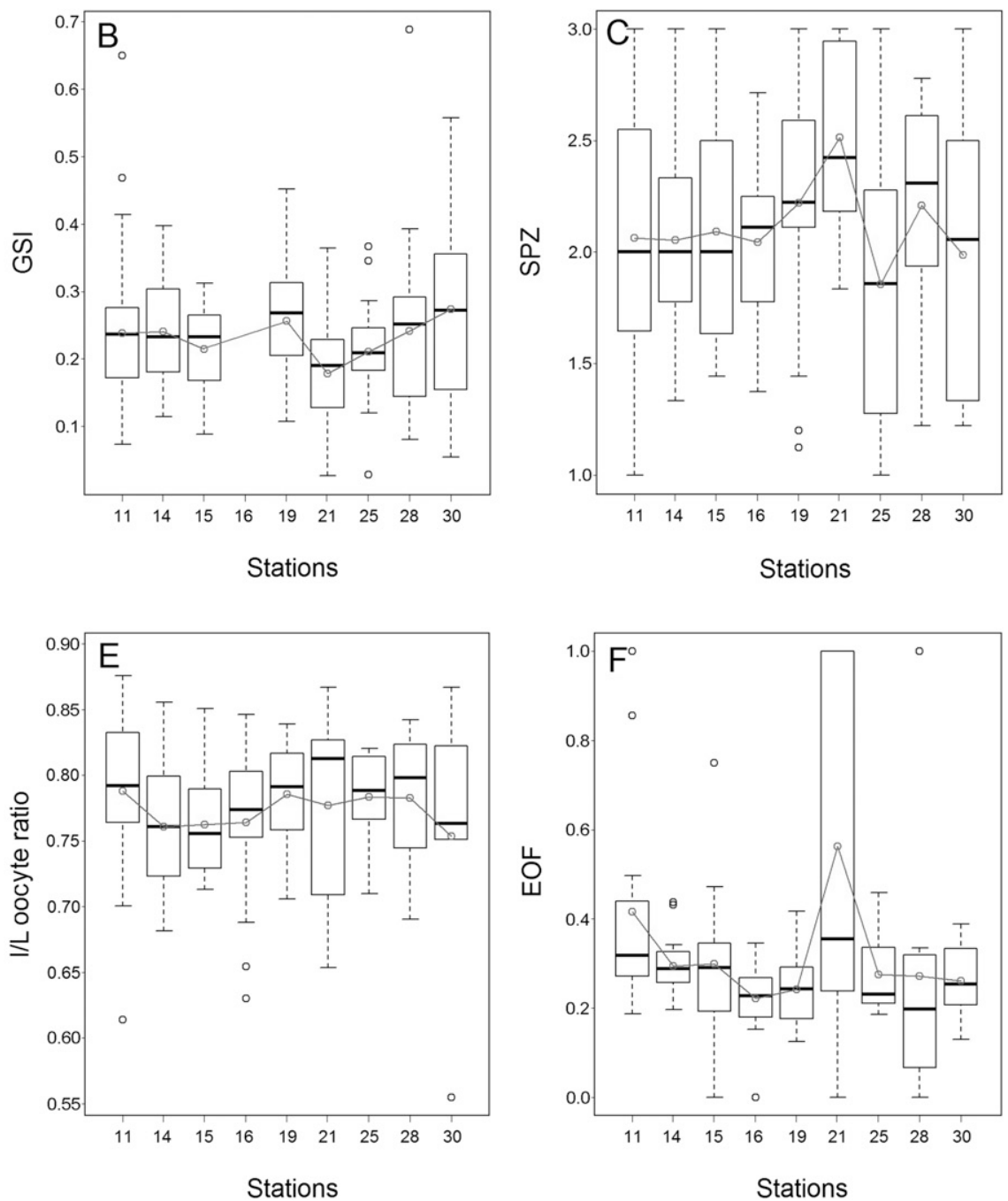

Figure 7. Boxplot distributions of values among stations for (A) GSR, (B) GSI, (C) SPZ, (D) oocyte diameter, (E) oocyte l/L ratio, and (F) EOF. Red dots represent arithmetic mean for each station. Mean values have been joined for easier visualization.

and their relationship with environmental forcing. This will be critical to understand the renewal of wild populations. A number of recommendations from gonad sampling to histological analyses can be made. First, sampling should ideally target a pool of specimens of homogeneous sizes. For remote islands, where small specimens are protected (as in French Polynesia) and large specimens increase travel costs and fixation constraints, sampling $12-14 \mathrm{~cm}$ giant clams is recommended. Fixative should be injected inside the gonad to ensure a thorough and complete fixation of gonad tissue. Unfixed samples should be discarded. Second, GSI should be used as the primary proxy for female maturity. It provides relevant and easily assessed information on female reproduction, which is the focus of many population dynamic models. Third, when histological snapshots of gonads are not subject to cost limitations, they should be performed at various gonad locations for the sake of representativeness. Longitudinal cuts through the middle of the gonad provide a fair compromise between covered surface and cost. In this case, indices characterizing the shape and size of oocytes are of interest (e.g., the mean oocyte diameter, perimeter, 1/L ratio, or area). Fourth, indices should always be assessed with consideration of GSR to avoid bias. Specifically, interpretation of female maturity stages should be performed on clams that are dominated by the female part. These recommendations provide new foundations for future studies on giant clam populations and for other molluscs with similar reproductive strategies as well.

\section{ACKNOWLEDGMENTS}

This work is part of SVW's PhD thesis and MM's Master thesis, and was supported by a $\mathrm{PhD}$ fellowship from the Ministère de l'Enseignement Supérieur et de la Recherche to the Université de la Polynésie française. Labex CORAIL also funded this study (TEKE-TEKE Project to NGL, SVW, GR, GLM, and SA). MM, SVW, NGM, and GLM designed the study. PL, MM, and SVW performed histological treatments, MM and SVW performed the analyses, and all co-authors contributed to writing the paper. The authors are grateful to DRMM (GR, J. Campanozzi-Tarahu, G. Haumani, and F. Faana), Secretariat of the Pacific Community (C. Wabnitz), and Tatakoto villagers (A. Rata and P. Maere) for their logistical support during field surveys. The ENTROPIE contribution number is 101 . 


\section{LITERATURE CITED}

André, C. \& M. Lindegarth. 1995. Fertilization efficiency and gamete viability of a sessile, free-spawning bivalve, Cerastoderma edule. Ophelia 43:215-227.

Andréfouët, S., S. Van Wynsberge, N. Gaertner-Mazouni, C. Menkes, A. Gilbert \& G. Remoissenet. 2013. Climate variability and massive mortalities challenge giant clam conservation and management efforts in French Polynesia atolls. Biol. Conserv. 160:190-199.

Barber, B. J. 1984. Reproductive energy metabolism in the bay scallop, Argopecten irradians concentricus (Say), Doctoral thesis, University of South Florida, Tampa. 122 pp.

Barber, B. J. \& N. J. Blake. 1981. Energy storage and utilization in relation to gametogenesis in Argopecten irradians concentricus (Say). J. Exp. Mar. Biol. Ecol. 52:121-134.

Barber, B. J. \& N. J. Blake. 1983. Growth and reproduction of the bay scallop, Argopecten irradians (Lamarck) at its southern distributional limit. J. Exp. Mar. Biol. Ecol. 66:247-256.

Barber, B. J. \& N. J. Blake. 2006. Reproductive physiology. In: Shumway, S. E. \& G. J. Parsons, editors. Scallops: biology, ecology and aquaculture. Amsterdam, The Netherlands: Elsevier. pp. 357-416.

Beasley, C. R., E. Tury, V. G. Vale \& C. H. Tagliaro. 2000. Reproductive cycle, management and conservation of Paxyodon Syrmatophorus (Bivalvia: Hyriidae) from the Tocantins river, Brazil. J. Molluscan Stud. 66:393-402.

Bell, L. J. \& J. C. Pernetta. 1988. Reproductive cycles and mariculture of giant clams in Papua New Guinea. In: Copland, J. W. \& J. S. Lucas, editors. Giant clams in Asia and the Pacific. Canberra, Australia: ACIAR Monograph. pp. 133-138.

Braley, R. D. 1984. Reproduction in the giant clams Tridacna gigas and $T$. derasa in situ on the north-central Great Barrier Reef, Australia, and Papua New Guinea. Coral Reefs 3:221-227.

Braley, R. D. 1988. Recruitment of the giant clams Tridacna gigas and T. deresa at four sites on the Great Barrier Reef. In: Copland, J. W. \& J. S. Lucas, editors. Giant clams in Asia and the Pacific. Canberra, Australia: ACIAR Monograph. pp. 73-77.

Byrne, M. 1998. Reproduction of river and lake populations of Hyridella depressa (Unionacea: Hyriidae) in New South Wales: implication for their conservation. Hydrobiologia 389:29-43.

Cano, J., M. J. Rosique \& J. Rocamora. 1997. Influence of environmental parameters on reproduction of the European flat oyster (Ostrea Edulis L.) in a coastal lagoon (Mar Menor, southeastern Spain). J. Molluscan Stud. 63:187-196.

Chavez-Villalba, J., C. Soyez, A. Huvet, Y. Gueguen, C. Lo \& G. Le Moullac. 2011. Determination of gender in the pearl oyster Pinctada margaritifera. J. Shellfish Res. 2:231-240.

Collin, R. 1995. Sex, size, and position: a test of models predicting size at sex change in the protandrous gasteropod Crepidula fornicata. Am. Nat. 146:815-831.

Delgado, M. \& A. Pérez-Camacho. 2007. Comparative study of gonadal development of Ruditapes philippinarum (Adams \& Reeve) and Ruditapes decussatus (L.) (Mollusca: Bivalvia): influence of temperature. Sci. Mar. 71:471-484.

Etheridge, R. E. 1996. Collections: preservation techniques, Museum of Zoology, University of Michigan. Accessed June 29, 2015. Available at: www.Isa.umich.edu/ummz/herps/collections/herp-prep.asp.

Gagné, F., C. Blaise, J. Pellerin, E. Pelletier, M. Douville, S. Gauthier-Clerc \& L. Viglino. 2003. Sex alteration in soft-shell clams (Mya arenaria) in an intertidal zone of the Saint Lawrence river (Quebec, Canada). Comp. Biochem. Physiol. C. Toxicol. Pharmacol. 134:189-198.

Gallucci, V. F. \& B. B. Gallucci. 1982. Reproduction and ecology of the hermaphroditic cockle Clinocardium nuttallii (Bivalvia: Cardiidae) in Garrison Bay. Mar. Ecol. Prog. Ser. 7:137-145.

Garen, P. 2003. Ponte et élevage larvaire de bénitier (Tridacna maxima). Accessed June 29, 2015. Available at: http://dx.doi.org/10.13155/28382.

Gibbons, M. C. \& M. Castagna. 1984. Serotonin as an inducer of spawning in six bivalve species. Aquaculture 40:189-191.
Gilbert, A., S. Andréfouët, L. Yan \& G. Remoissenet. 2006. The giant clam Tridacna maxima communities of three French Polynesia islands: comparison of their population sizes and structures at early stages of their exploitation. ICES J. Mar. Sci. 63:1573-1589.

Grant, A. \& P. A. Tyler. 1983. The analysis of data in studies of invertebrate reproduction. I. Introduction and statistical analysis of gonad indices and maturity indices. Int. J. Invertebr. Reprod. Dev. 6:259-269.

Griffiths, C. L. \& D. W. Klumpp. 1996. Relationships between size, mantle area and zooxanthellae numbers in five species of giant clam (Tridacnidae). Mar. Ecol. Prog. Ser. 137:139-147.

Hold, N., L. G. Murray, H. Hinz, S. P. Neill, S. Lass, M. Lo \& M. J. Kaiser. 2013. Environmental drivers of small scale spatial variation in the reproductive schedule of a commercially important bivalve mollusc. Mar. Environ. Res. 92:144-153.

Howard, D. W. \& C. S. Smith. 1983. Histological techniques for marine bivalve mollusks. Oxford, MD: Oxford Laboratory, National Marine Fisheries Service. 95 pp.

Jameson, S. C. 1976. Early life history of the giant clams Tridacna crocea Lamarck, Tridacna maxima (Röding), and Hippopus hippopus (Linnaeus). Pac. Sci. 30:219-233.

Joaquim, S., D. Matias, B. Lopes, W. S. Arnold \& M. B. Gaspar. 2008. The reproductive cycle of white clam Spisula solida (L.) (Mollusca: Bivalvia): implications for aquaculture and wild stock management. Aquaculture 281:43-48.

Juhel, G., S. C. Cuilloty, R. M. O'Riordan, J. O'Connor, L. De Faoite \& R. McNamara. 2003. A histological study of the gametogenic cycle of the freshwater mussel Dreissena polymorpha (Pallas, 1771) in Lough Derg, Ireland. J. Molluscan Stud. 69:365-373.

Lacoste, E., G. Le Moullac, P. Levy, Y. Gueguen \& N. GaertnerMazouni. 2014. Biofouling development and its effect on growth and reproduction of the farmed pearl oyster Pinctada margaritifera. Aquaculture 434:18-26.

Lango-Reynoso, F., J. Chávez-Villalba, J. C. Cochard \& M. Le Pennec. 2000. Oocyte size, a means to evaluate the gametogenic development of the Pacific oyster, Crassostrea gigas (Thunberg). Aquaculture 190:183-199.

Lefort, Y. \& J. Clavier. 1994. Reproduction of Annachlamys flabellata, Comptopallium radula and Mimachlamys gloriosa (Mollusca: Pectinidae) in the south-west lagoon of New Caledonia. Aquat. Living Resour. 7:39-46.

Lewis, A. D., T. J. H. Adams \& E. Ledua. 1988. Fiji's giant clam stocks - a review of their distribution, abundance, exploitation and management. In: Copland, J. W. \& J. S. Lucas, editors. Giant clams in Asia and the Pacific. Canberra, Australia: ACIAR Monograph. pp. 66-72.

Marteil, L. 1960. Ecologie des huîtres du Morbihan Ostrea edulis Linné et Gryphaea angulata Lamarck. Rev. Trav. Inst. Peches Marit. 24:329-446.

Marteil, L. 1976. La conchyliculture française. $2^{\circ}$ Partie: biologie de l'huître et de la moule. Rev. Trav. Inst. Peches Marit. 40:149-346.

Mason, J. 1958. The breeding of the scallop (Pecten maximus L.) in Manx waters. J. Mar. Biol. Ass. U.K. 37:653-671.

McKoy, J. L. 1980. Biology, exploitation and management of giant clams (Tridacnidae) in the Kingdom of Tonga. Fish Bull. 1:17-25.

Mies, M. \& P. Y. G. Sumida. 2012. Giant clam aquaculture: a review on induced spawning and larval rearing. Int. J. Mater. Sci. 2:62-69.

Nash, W. J., R. G. Pearson \& S. P. Westmore. 1988. A histological study of the reproduction in the giant clam Tridacna gigas in the northcentral Great Barrier Reef. In: Copland, J. W. \& J. S. Lucas, editors. Giant clams in Asia and the Pacific. Canberra, Australia: ACIAR Monograph. pp. 89-94.

Navneel, K. S. \& K. Azam. 2013. Comparative study of available spawning methods of the giant clam Tridacna squamosa (Bivalvia: Tridacnidae) in Makogai, Fiji. World J. Fish \& Marine Sci. 5:353-357. 
Norton, J. H. \& G. W. Jones. 1992. The giant clam: an anatomical and histological atlas. Canberra, Australia: ACIAR Monograph. 142 pp.

Popovic, Z., I. Mladineo, D. Ezgeta-Balic, Z. Trumblic, N. Vrgoc \& M. Peharda. 2013. Reproductive cycle and gonad development of Venus verrucosa L. (Bivalvia: Veneridae) in Kastela Bay, Adriatic Sea. Mar. Biol. Res. 9:274-284.

Pouvreau, S., A. Gangnery, J. Tiapari, F. Lagarde, M. Garnier \& A. Bodoy. 2000. Gametogenic cycle and reproductive effort of the tropical blacklip pearl oyster, Pinctada margaritifera (Bivalvia: Pteriidae), cultivated in Takapoto atoll (French Polynesia). Aquat. Living Resour. 13:37-48.

Ram, J. L., P. P. Fong \& D. W. Garton. 1996. Physiological aspects of zebra mussel reproduction: maturation, spawning, and fertilization. Am. Zool. 36:326-338.

Rheman, S., M. L. Islam, M. M. R. Shah, S. Mondal \& M. J. Alam. 2002. Observation on the fecundity and gonadosomatic index (GSI) of grey mullet Liza parsia (Ham.). Online J. Biol. Sci. 2:690-693.

Richard, G. 1982. Mollusques lagunaires et récifaux de polynésie française, inventaire faunistique, bionomie, bilan quantitatif, croissance, production. Doctoral thesis, Université Pierre et Marie Curie Paris VI. 153 pp.

Rose, R. A., R. E. Dybdahl \& S. Harders. 1990. Reproductive cycle of the Western Australian silverlip pearl oyster, Pinctada maxima (Jameson) (Mollusca: Pteriidae). J. Shellfish Res. 9:261-272.

Sastry, A. N. 1970. Reproductive physiological variation in latitudinally separated populations of the bay scallop, Aequipecten irradians Lamarck. Biol. Bull. 138:56-65.

Shelley, C. C. \& P. C. Southgate. 1988. Reproductive periodicity and morphometry of Hippopus hippopus and Tridacna crocea. In: Copland, J. W. \& J. S. Lucas, editors. Giant clams in Asia and the Pacific. Canberra, Australia: ACIAR Monograph. pp. 21-32.

Smith, S. D. A. 2011. Growth and population dynamics of the giant clam Tridacna maxima (Röding) at its southern limit of distribution in coastal, subtropical eastern Australia. Molluscan Res. $31: 37-41$.

Soo, P. \& P. A. Todd. 2014. The behaviour of giant clams (Bivalvia: Cardiidae: Tridacninae). Mar. Biol. 161:2699-2717.

Urban, H. J. 2000. Culture potential of the pearl oyster (Pinctada imbricata) from the Caribbean. I. Gametogenic activity, growth, mortality and production of a natural population. Aquaculture 189:361-373.

Urban, H. J. \& J. M. Riascos. 2001. Estimating gonado-somatic indices in bivalves with fused gonads. J. Shellfish Res. 21:249-253.

Vélez, A., E. Alifa \& O. Azuaje. 1990. Induction of spawning by temperature and serotonin in the hermaphroditic tropical scallop, Pecten ziczac. Aquaculture 84:307-313.

Williams, J. R. \& R. Babcok. 2010. Assessment of size at maturity and gonad index methods for the scallop Pecten novaezelandiae. $N$. Z.J. Mar. Freshw. Res. 39:851-864.

Wintermyer, M. L. \& K. R. Cooper. 2007. The development of an aquatic bivalve model: evaluating the toxic effects on gametogenesis following 2,3,7,8-tetrachlorodibenzo-p-dioxin (2,3,7,8-TCDD) exposure in the eastern oyster (Crassostrea virginica). Aquat. Toxicol. 81:10-26.

Yusa, Y. 2007. Causes of variation in sex ratio and modes of sex determination in the Mollusca - an overview. Am. Malacol. Bull. 23:89-98.

Zanini, J. M. 1994. Stocks naturels de nacres-Pinctada margaritifera-de Polynésie française. Doctoral thesis, Ecole Pratique des Hautes Etudes. 197 pp. 